\title{
o8-Fatma Aliye’nin Enîn romanında kadının ev içi gündelik yaşamı
}

\section{Cennet ALTUNDAŞ ${ }^{1}$}

APA: Altundaş, C. (2020). Fatma Aliye’nin Enîn romanında kadının ev içi gündelik yaşamı. RumeliDE Dil ve Edebiyat Araştırmaları Dergisi, (Ö8), 114-127. DOI: 10.29000/rumelide.814082.

\section{$\ddot{\mathbf{O} z}$}

Modernleşme dönemi Türk romanında mekân, toplumsal değişimi yansıtan başat unsurlar arasındadır. Romanda mekân ve mekân içindeki insan toplumsal yaşamı, değişimi ve dönüşümünü yansıtmaktadır. Bu bağlamda "ev" önemli bir roman mekânıdır. Türk edebiyatının ilk dönem romanlarında ev mahremdir ve kadına aittir. Dolayısıyla romanlardaki ev içi yaşam ve kadın karakterler arasındaki ilişki dönemin kadınlarının mahrem alandaki gündelik yaşamını bize vermektedir. Özellikle Batılılaşmanın etkisiyle gelenek ve modernite arasında sıkışan kadının ev içi yaşamı da bu durumdan etkilenir; buna bağlı olarak değişir ve dönüşür. Modern dünyada gündelik yaşamın yükü kadınlar üzerindedir. Kadın, gündelik yaşamda hem özne hem nesne durumundadır. Edebî eserler, yazıldıkları dönemin gündelik yaşamını işlerken hem yazarın yaşamından izler hem de anlattıkları zamandan ve mekândan izler taşır. Bu çalışmada Enîn romanı merkeze alınarak kadınların evde nasıl zaman geçirdiği, ev içi rutinleri, evdeki kadınlar arası ilişkiler, ev içi görev dağılımları, evde kadına ait alanlar, ev içi yaşamın dönemin gündelik yaşamına dair hangi ipuçlarını verdiği, ev içi yaşamın zamanla nasıl gelişip dönüştüğü değerlendirilecektir. Yazıldığı dönemin kadınlarının gündelik yaşayışını, o dönemin bir kadın yazarının bakış açısından anlatan Enîn, mekân olarak üç farklı yalıda yaşayan kadınların yaşamları üzerine kurulmuştur. Bu yüzden ev içi gündelik hayat pratiklerini ayrıntılı olarak veren bir romandır.

Anahtar kelimeler: Gündelik yaşam, kadın, Türk romanı, Fatma Aliye, Enîn

\section{Everyday life of women in the home of Fatma Aliye's Enin novel}

\begin{abstract}
In the Turkish novel of modernization period, space is among the dominant elements reflecting the social change. Space and the human in the space in the novel reflects social life, change and transformation. In this context, "home" is an important novel space. In the early novels of Turkish literature, the home is private and belongs to the women. Therefore, the relationship between domestic life and female characters in novels gives us the daily life of the women of the period in the intimate space. Especially the domestic life of the woman who is stuck between tradition and modernity with the effect of Westernization is also affected by this situation; it changes and transforms accordingly. In the modern world, the burden of daily life is on women. Women are both subject and object in daily life. Literary works bear traces of both the author's life and the time and place they narrate while they are covering the daily life of the period they were written. In this study, the domestic life of women, which constitutes an important part of daily life, will be evaluated within the framework of Fatma Aliye's novel named Enîn. Enîn tells the daily life of the women of the period in which it was written, from the perspective of a woman writer of that period
\end{abstract}

Arş. Gör., Hacettepe Üniversitesi, Edebiyat Fakültesi, Türk Dili ve Edebiyatı Bölümü (Ankara, Türkiye), cennet.altundas@hacettepe.edu.tr, ORCID ID: 000o-0002-4508-6472 [Makale kayit tarihi: 12.09.2020-kabul tarihi: 20.11.2020; DOI: 10.29000/rumelide.814082]

Adres

Osmanağa Mahallesi, Mürver Çiçeği Sokak, No: 14/8 Kadıköy / Istanbul / TÜRKIYE e-posta: editor@rumelide.com +90 (505) $7958124 /+90(216) 7730616$ 
and the novel is based on the lives of women living in three different mansions. Therefore, it is a novel that gives detailed daily life practices at home. In this study, in the focus of the novel in question, how women spend time at home, their home routines, relationships between women at home, distribution of domestic tasks, areas belonging to women at home, what clues domestic life gives about the daily life of the period, and how domestic life evolved and transformed over time will be evaluated.

Keywords: Daily life, women, Turkish novel, Fatma Aliye, Enîn

\section{Giriş}

Enîn, Fatma Aliye'nin eserleri arasında mekân vurgusu ile öne çlkan bir romandır. Son dönem Osmanlı toplumunun zengin ailelerinin yalılardaki yaşamını anlatan romanın temel konusu doğru eş seçimi, mutlu bir evlilik hayatı, yanlış tercihlerin yol açacağı mutsuzluklardır. Romanda yan yana üç yalıda yaşayan ailelerin yaşamları, evlilik çağındaki çocuklarını evlendirme istekleri merkezinde ele alınmıştır. Ailelerin çocukları için uygun eş seçimi ve çocuklarının mutluluğu ile aile içi ilişkiler arasında paralellik vardır. Aile içi ilişkilerin iyi olması gençlerin mutlu bir evlilik yapması ya da mutsuz olacakları bir evlilikten kaçınmasına yardımcıdır.

Fatma Aliye'nin romanlarında evden kaçan ve eve sığınan kadınları incelediği makalesinde Şahika Karaca ev ve kadın ilişkisini şu şekilde değerlendirmiştir:

Bilindiği üzere ataerkil sistemde kamusal alanlar eril özellikler taşır. Bu sistem içerisinde kadınlara uygun görülen mekânlar ise ev içi mekânlardır. Kadının iç mekânla yani evle özdeşleştirilmesi ise kadın bedeninin fitne unsuru olarak algılanmasındandır. Bu sebeple ataerkil sistem toplumsal dinamiklerin zarar görmemesi için mekânı sıkı bir biçimde denetleyerek bu sorunu gidermeye çalışır. Harem-mahrem ilişkisi de bu durumu açıklayıcı niteliktedir. Böylece dış mekân/sokak/özne/erkek, iç mekân/ev/nesne/kadınla birleşir (Karaca, 2013, s.1818).

Çok sayıda kadın karakterin işlendiği Enîn romanında, kadınların yaşamı "ev içi yaşam"dan ibarettir. Dış dünyayla bağları yoktur. Dönemin İstanbul'unda gezdiklerini ya da herhangi bir sebeple evlerinden dışarıya çıktıklarını görmeyiz. Düğün alışverişi bile eve gelen terzilerle, kataloglarla yapılır. Ev içi yaşamın bu kadar yoğun görüldüğü bu roman, dönemin kadınlarının ev içi gündelik yaşam pratiklerine dair pek çok ayrıntıyı içermektedir.

Lefebvre, gündelik hayatın ne olduğu sorusuna şu cevabı verir: "Gündelik hayat nedir ki? Ekonomik, psikolojik veya sosyolojiktir, özel yöntemler ve yollarla kavranması gereken özel nesneler ve alanlardır. Beslenmedir, giyinmedir, eşyadır, evdir, barınmadır, komşuluktur, çevredir” (2016, s.32). Gündelik hayat sıradan tekrarların, rutinin alanıdır. Gündelik hayatı eleştirmek aslında insanların yapıp etmelerinde üstü örtülü olanı dolayısıyla görülemeyeni ortaya çıkarmaktır. Bu bağlamda edebî eserler, görünmez kılınmış, yer altına itilmiş gündeliği kavramanın yollarından biridir. Edebiyat, yazıldığı ve konu edindiği dönemin gündeliğini tartışmaya açar. Kurmaca metinlerde gündelik hayat iki şekilde kendine yer bulur: yazarın gündelik yaşamının yansımaları ve kurmacanın içinde temsil edilen gündelik yaşamın kendisi (Taş, 2011, s.9). Enîn romanında hem Fatma Aliye'nin gündelik yaşamının izleri hem de roman kişilerinin gündelik yaşamına dair detaylar vardır. Yazar, yaşadığı dönemde şahit olduğu hayatı romanında anlatmıştır.

Ev içi gündelik yaşam denildiğinde yeme içmeden ev düzenine kadar her şey akla gelmektedir. Suraiya Faroqhi'ye göre gündelik kültür çok geniş bir kavramdır. Komşu ziyaretlerinde dikkat edilmesi gereken

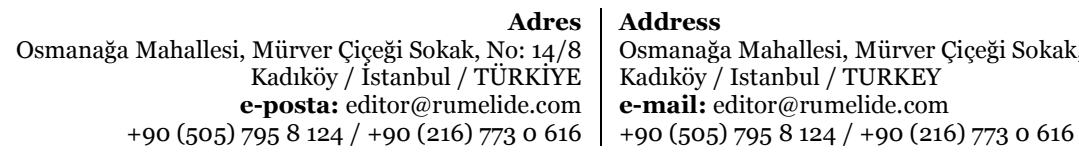


nezaket kurallarından, yemeğin nasıl hazırlandığına ya da çocukların nasıl yetiştirilmesi gerektiğine dair pek çok öğeyi içermektedir. Gündelik kültürde renklere yüklenen anlamlardan, erkeklerin kahvehanelerde ya da kadınların örgü örerken anlattıkları hikâyelere kadar pek çok konuya yer vardır (Faroqhi, 2005, s.4). Enîn romanına baktığımızda kadınların gündelik yaşamlarının merkezini eş seçimi oluşturmaktadır. Aile içi ilişkiler, kadınlar arası sorunlar, romandaki kadın-erkek ilişkileri, kadınların eğitimi, maddi durum, ev işleri ve eğlence anlayışları evlilik konusu etrafında şekillenmektedir.

Çalışmada gündelik yaşamın mekân ile ilişkisi ortaya konulduktan sonra Enîn romanında kadınların ev içi yaşamı aile içi ilişkiler, kadın - erkek ilişkileri, kadınların kılık kıyafetleri, ev içi eğlenceler, müzik, düğün, ev gezmeleri, bahçe gezintileri ve ev içi eğitim başlıkları altında değerlendirilmiştir.

Romanın yapı taşları arasında olan mekân, roman kişileri ve olay örgüsü ile yakın ilişki içindedir. Enîn romanında mekân evdir. Romanda olaylar yan yana üç yalıda geçmektedir. Mehmet Tekin'e göre romanda mekân, uygarlığın ve uygarlaşmanın vitrinidir. Yazar, eserinde mekân sayesinde bir dönemin geleneklerini, eşya çeşitliliğini, mobilya ve mefruşat tarzını, giyime ve eğlenceye dönük alışkanlıkları, modayı, argoyu ve günlük konuşmayı okuyucuya gösterir. Bu sayede roman, o günkü toplumun aynası haline gelir (Tekin, 2011: 131). Ev, insanın en korunaksız ve yalın halde olduğu mekândır. Evin eşyaları, evde süren hayat tarzı, evde misafir ağırlama biçimi, ev içi işler bütün bunlar yaşanan toplumun kültürünü yansıtır. "Türk romanında ev, 19. yüzyılın ortalarından itibaren hızlanarak yayılan batılılaşma eksenli değişim süreçlerini yansıtan önemli bir unsur olarak dikkati çekmektedir" (Elçi, 2003: 21). Enîn'de kadınların ev içi eğitimi, Fransızca ve İngilizce öğrenmeleri, çaldıkları müzik aletleri batılılaşmanın etkisini hissettirir. Evde misafir ağırlama, düğün âdetleri, kadın erkek ilişkisindeki sınırlar ise anlatılan zamanın toplumsal kültürüne dair önemli ipuçlarını içermektedir.

Enîn romanında dönemin zengin, kültürlü, önde gelen ailelerin çocuklarının kadın - erkek ilişkileri, eş seçimleri, evlilik ve aile içi hayatları, kadın merkezli anlatılır. Romanda öne çıkan üç mekân: Sabahat Hanım'ın yalısı, Fehame'nin yalısı ve Sabite Hanım'ın yalısıdır. Romanda mekân olarak yalının seçilmesi önemlidir. Aynı toplumsal tabakalara hitap ettiği için köşk, konak, yalı birlikte düşünülmelidir. Buna bağlı olarak konak, köşk ve yalı büyüklük, genişlik ve zenginlikle eşdeğerdedir. Toplumun üst sınıfının evidir. Zenginler, paşalar, âlimler, bürokratlar böylesi evlerde ikamet eder. Ayrıca bu evler, geniş aileyi ve hizmetçileri, dadıları, mürebbiyeleri çağrıştırır. Zenginliğin çeşitli biçimlerde sergilendiği bu evlerin ayrılmaz parçaları lüks eşyalar, gösterişçi tüketim, şatafatlı ve zengin sofralar, çeşitli eğlenceler ve önemli toplantılardır. Sonuç olarak konak, yalı ve köşk gibi zenginlik ifade eden mekânlar belli bir hayat tarzının, medeniyet algısının mekâna yansıyan resmidir (Alver, 2019, s. 126). Romandaki üç yalıda da bahsedilen detayları görmek mümkündür. Pahalı kıyafetler, her evde piyano, cariyeler, özel hocalar ile ev içi eğitim, gösterişli düğün hazırlıkları romanda yer alan zenginlik unsurları arasındadir.

Roman, kadın karakterler yönünden zengin bir romandır. Romanın merkez kişisi Sabahat Hanım'dır. Ailesini küçük yaşta kaybeden, dayısı tarafından büyütülen Sabahat çok zengindir. Cariyesi İtimat, babasının ikinci karısı Sabite Hanım ve üvey kardeşi Nebahat de Sabahat'in yalısında yaşamaktadırlar. Diğer yalıda Sabahat'in ablası Mesile Hanım, cariyesi Piraye, oğlu Rıfat ve kocası ile birlikte yaşamaktadır. Romandaki üçüncü yalı Fehame Hanım ve ailesinindir. Fehame Hanım’n annesi Lütfiye Hanım ve iki gelini vardır. Hikâyenin esas örgüsünü oluşturan bu üç ailenin kadınları dışında ev işlerini yapan isimsiz cariyeler ve misafirliğe gelen kadınlar da vardır. Roman mekânın ev yani yalı

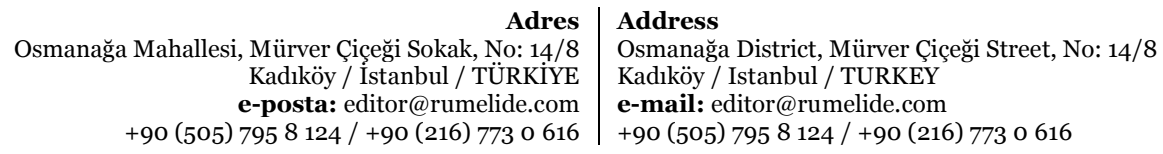


olması, olayların önemli bir kısmının evde geçmesi ve kadın karakterlerin bolluğu açısından, dönemin kadınlarının gündelik yaşamına dair zengin ayrıntılar içermektedir.

\section{Aile içi ilişkiler}

Romanın ana konusu evlilik ve eş seçimidir. Ama aile içi ilişkiler romanda en az evlilik konusu kadar detaylı işlenmiştir. Yazara göre aile içi ilişkiler kötüyse gençlerin eş seçimleri ve evlilikleri de kötü olmaktadır. Romanda bu durum Fehame ile okuyuculara gösterilmiştir.

Ailesi ile ilişkileri en kötü durumda olan Fehame'dir. Babasından, annesinden, ağabeylerinden hatta yaşça kendisine yakın yengelerinden bile sevgi ve şefkat göremez. En büyük hayali merhametli bir koca bulup o yalıdan kurtulmaktır. Ama kendisine gelen görücüleri aile her defasında reddeder. Çünkü niyetleri kızlarına iç güveysi alıp onu evden göndermemektir. Fehame, ailesinden çektiklerini arkadaşı ve akrabası Müeyyet'e anlatır:

Sev kardeşim beni sev! Zira benim sevilmeğe pek ihtiyacım var! Bu ailede her şey var, para, mücevher, debdebe!... Lâkin muhabbet yok! Ben ise muhabbeti her şeye tercih ederim. Dünyada hiçbir şeye gıpta etmedim yalnız aileler arasındaki muhabbete gıpta ediyorum (s.303)².

Ailesi tarafından sevilmeyen Fehame, zorla evlendirildiği kocası tarafından da sevilmez. Evliliklerinin ilk aylarından itibaren kocası geceleri eve geç gelmeye başlar. Roman boyunca Fehame mutlu olamaz. İyi ilişkiler kurduğu tek kişi Sabahat olur.

Romanda anne eksikliği Fehame'nin hayatında önemli bir rol oynar. Bu eksiği özel ders aldığı hocalarının gözüne girerek, Sabahat'ten ve Müeyyet Hanım'dan sevgi bekleyerek gidermeye çalışır. Evlilik hayalinde bile tek amacı kendisini gerçekten seven bir erkekle ailesinin evinden kurtulmak ve mutlu olmaktır.

Romanda aile içi ilişkilerde kötü anne modeli olarak Fehame'nin annesi Lütfiye Hanım başı çekmektedir. Kızını istemediği bir adamla evlendirir. Kendi istekleri ve mutluluğu için kızını mutsuz etmeyi göze alır. Evde gelinleri, oğulları hatta eve gelen giden komşu kadınlar bile kızını azarlarken Lütfiye Hanım bunlara engel olmaz; aksine destek bile olur. Yazar romanda Lütfiye Hanım'ın anneliğini şu cümleler ile anlatır: "Fehame’nin validesi Lütfiye Hanım rahatını ve hoş zaman geçirmeği düşünen bir hanım olduğundan evlatlarını dadılar eline bırakmış idi. Lütfiye Hanım alayiş ve debdebeyi pek sever, kendini medh ü sena ettirmekten pek mahzuz olurdu” (s.338). Roman boyunca Lütfiye Hanım sadece kendisini düşünür. Kızının düğününde bile dalkavuklarına hediyeler alır. Başkalarının ne dediğini önemser ama kızının mutluluğunu önemsemez.

Romanın diğer ailesi ise Mesile Hanım'ın ailesidir. Mesile Hanım ve ailesinin ilişkileri eş seçimi etrafında şekillenmiştir. Çok sevdiği cariyesi Piraye ile oğlunu evlendirmek, Mesile Hanım’ın ve eşi Bahir Efendi'nin en büyük isteğidir. Bu istek aile içi çatışmalara ve felaketlere neden olmuştur. Piraye, Rıfat'ın evlenmeyi kabul etmemesi üzerine aşkından verem olup ölmüştür. Rıfat tedavisi zor bir hastalığa yakalanmıştır. Bu felaketler, Mesile Hanım ve ailesi için bir dönüm noktası olmuştur. Yaşanan felaketten sonra evlilik konusunda oğullarının istek ve görüşlerini dikkate almaya başlarlar. Yazı boyunca Fatma Aliye’nin romanından alıntılar şu kaynaktandır: Fatma Aliye (2015). Enîn. (Hzrl. Tülay Gençtürk
Demircioğlu). İstanbul: Boğaziçi Üniversitesi Yayınevi.

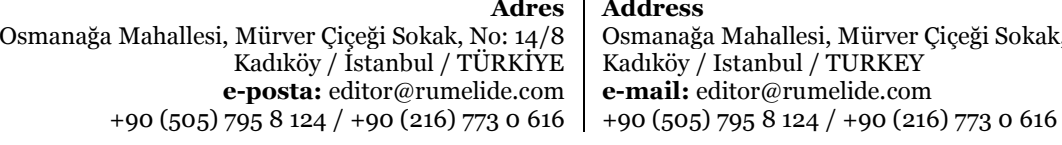


Romanda anne-evlat çatışması, kardeşler arası çatışmalar başlıkları altında değerlendirebileceğimiz aile içi çatışma örnekleri görülmektedir. Fehame ile annesi Lütfiye Hanım arasındaki çatışma tek yönlüdür. Anne, kızını doğduğu andan itibaren yeterince sevmez. Fehame büyüdükçe çatışma da büyür. Ama bu çatışma tek taraflıdır. Fehame roman boyunca ailesine haklı bile olsa asla karşı çımaz. Mesile Hanım ve oğlu Rıfat arasındaki çatışma eş seçimi söz konusu olduğunda başlar. Mesile Hanım, oğlunu Piraye ile evlendirmek ister ama Rıfat kabul etmez. Oğlunun sevdiği kız yüzünden hasta olması, Fehame'nin başkası ile evlenmesi ve Piraye'nin ölmesi Rıfat ve Mesile Hanım arasındaki çatışmayı sona erdirir. Anne ve oğul her ikisini de mutlu edecek başka bir kızla evlilik konusunda anlaşırlar (s.449). Sütude Hanım'ın oğulları Nihat ve Suat ile çatışması da evlilik ve eş seçimi yüzündendir. Nihat evlenmek istemez; Suat ise ailesinden gizli Nebahat'la evlenir (s.416). Evlilik ve eş seçimi konusu romandaki aile içi çatışmaların temel sebebidir.

Kardeşler arası çatışmanın en büyük örneği Sabahat ve Nebahat arasındaki çatışmadır. Roman boyunca bu durumun bütün suçlusu olarak Nebahat gösterilmiştir. Annesi Sabite Hanım kızından dert yanar: "Kardeşim! Bu kızı ıslah edebilmekten ümidimi kestim. Velinimeti olan ablasını kıskanmaktan vazgeçirmek mümkün olmuyor. Bir düziye Sabahat'e sataşmak, taşlar atmak ile telezzüz ediyor." (s.254). Nebahat'i bu derece kıskanç yapan aslında anne ve babasının her zaman Sabahat'i sevmesidir. Romanda Sabahat'in ailesine dair yaşadı̆̆ tek sorun ve çatışma üvey kardeşi Nebahat iledir. Sabahat'in annesi ölünce babası Sabite Hanım'la kızı Sabahat'e anne olması için evlenir. Sabite Hanım evliliğinin ilk yılında kızı Nebahat doğduğunda onu dadıya emanet edip Sabahat'le ilgilenmeye devam eder. Çocukluktan gelen bu sorunların üzerine bir de Nebahat'in evlenmek ve rahat bir hayat sürmek istediği Suat'ın ablası ile nişanlanması çatışmayı büyütür. Nebahat, ablasından ve ailesinden intikam almak için Suat'ı tuzağa düşürür ve ablasından ayırıp kendisi evlenir. Bu durum Sabahat ve ailesinin yaşadığı en büyük aile krizidir. Romanda çok öne çıkarılmasa da Suat ve Nihat arasında da Nebahat yüzünden bir çatışma çıkar. Nihat, Suat'ın gece vakti Nebahat'le bahçede yalnız buluşmasına hiçbir zaman hak vermez (s.404). Ama bu çatışma çok büyümez. Çünkü Suat önce yalıyı terk eder; sonra gizlice evlenir.

Romanda aile içi ilişkileri şekillendiren otoritedir. İlişkilerde bu otorite saygı ve para üzerine kuruludur. Romanda aile büyüklerine saygısızlık edilmez. Kardeşler abla ve ağabeylerini, çocuklar ve gençler ise aile büyüklerini sayıp severler. Ama otoriteyi belirleyen en önemli güç paradır. Nebahat'e göre Sabahat'in sevilmesinin sebebi parasının olmasıdır (s.254). Roman boyunca evdeki çalışanların, eğitim için eve gelen hocaların parasını veren; üvey annesi Sabite Hanım’ın geçimine yardımcı olan, dayısı ve yengesini kendi yalısında kalmasını kabul eden Sabahat'tir. Kendi düğün hazırlıklarını kendi parasıyla yapmıştır. Bu maddi durum, Sabahat'in otoritesini artırmış ve sözüne saygı duyulmuştur. Özellikle Suat'la evlenmekten vazgeçmeye tek başına karar vermesi, aile büyüklerinin onun kararına saygı duyması bu otoritenin göstergesidir.

\subsection{Kadın - erkek ilişkileri}

Fatma Aliye, Enîn'de kadın-erkek ilişkilerini mekân ortaklığı üzerine kurgulamıştır. Sabahat ve Suat kuzendirler; Sabahat'in anne ve babası öldüğü için dayısı gelip Sabahat'in yalısında yaşamaya başlamıştır. Bu sayede dayısının oğulları Suat ve Nihat'la Sabahat ve Nebahat beraber büyümüşlerdir. Suat ve Sabahat aynı evde yaşadıkları için bahçede gezinip evliliklerini konuşma fırsatı bulabilmiştir.

Yine romanda evlenmesi istenen Rıfat ve Piraye de aynı evde büyümüşlerdir. Piraye, eve cariye olarak alınmış ama evin büyükleri tarafından kız evlat yerine konulmuştur. Rıfat ise bitişiklerindeki yalının

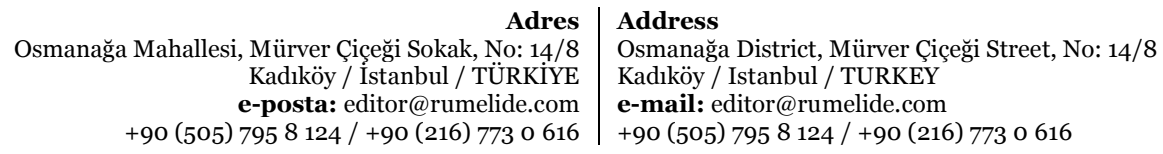


bahçesinde birkaç kez gördüğü Fehame'ye âşık olmuştur. Onunla konuşma firsatı bulamamıştır. Ama ailesini ikna edip Fehame'ye görücü yollamıştır.

Piraye aynı evde kardeş gibi büyüdüğü Rıfat'a âşık olur. Rıfat'ın dikkatini çekmek için her yolu dener. Bu noktada Piraye'nin önemli bir fedakârlığı söz konusudur. Piraye, evin cariyesi olduğu halde özgür bir kadın olarak yetiştirilmiş, cariyelik ya da odalık ihtimali asla düşünülmemiştir. Rıfat, hasta olunca Piraye ona bakmak ve hizmetlerini görmek için Rıfat'ın odasında yatıp kalkmaya başlar. Bu durum Rıfat'ın dikkatinden kaçmaz: "Piraye'nin hanımlık mevkiinden cariyelik mevkiine indirilmesi onun böyle benim odamda yatacak kadar mahremiyetini hissettirmek için mi imiş? Belki beni de oyalamak istiyorlar" (s.425). Piraye, hastalık boyunca hatta Rufat iyileştikten sonra da odada kalmaya devam eder. Ama Rıfat tarafından odadan kovulur. Bu, Piraye için ölümcül bir darbe olur. Yatağa düşer ve kısa zamanda da veremden ölür. Hanımlıktan cariyeliğe inmeyi sevdiği adam için kabul eden Piraye isteğine ulaşamaz.

Nebahat de Suat ve Nihat'la beraber büyümüştür. Suat zengin olduğu için onunla evlenmek ister. Ama Suat'ın ablası ile nişanlanması sonrası Nihat'la evlenmeye çalışır. Ona yaklaşmak için her firsatı dener. Bu durum Nihat'ın dikkatini çeker ve rahatsız olur. Ama Suat, Nebahat'in tavırlarındaki ikiyüzlülüğü göremez ve onun tuzağına düşer. Nihat'a göre ağabeyinin en büyük suçu Nebahat'e inanıp onunla gece vakti bahçede yalnız görüşmesidir. Böyle bir görüşmeye gelirken Nebahat'in açı giyinmesi bile bir işaret olmalıydı: "İşte karının o hayâsızca kıyafeti sana nasıl tuzaklar hazırladığına kifayet etmeli idi. Onu o halde görünce hemen nefretle geri dönmeli, kaçmalı idin” (s.403). Ama Suat, Nebahat'in kendisine olan bu ilan-ı aşkından memnun olur. Suat’ın bu zaafı ve zayıflığı Sabahat'i ve ailesini kaybetmesine neden olur. Kimselere haber vermeden Nebahat'le evlenir. Aile tarafindan kabul edilmeyen bu ilişki, Suat ve Nebahat'in aileden dışlanmasına neden olur.

Sabahat romanda hem eğitim hem de ahlak yönünden örnek bir kadın olarak çizildiği için Suat ile ilişkisi yazar tarafından özellikle sınırlı tutulur. Bahçede evlilik hakkında konuşurlarken Suat, küçüklüğünden beri yaptığı gibi Sabahat’in elini öpmek ister. Sabahat ciddi bir tavırla:

Hayır Suat! Şimdiye kadar yekdiğerimize kardeș muamelesinde bulunduğumuz için ben sizin elinizi öpüyordum siz de benim elimi bûs ediyordunuz. Dikkat etmediniz mi ki bu defa geldiğinizde ben elinizi öpmedim. Evvelce İslam kadınlarında genç kızlarla erkekler görüşerek, tanışarak izdivaç ederlerken muamele-i dest-bûsî filan gibi şeyler olmazdı. Elleri ellerine dokunmaksızın namzetlik zamanı geçerdi. Bizim nişanlılık zamanımız da öyle alaturka geçmelidir (s.281).

Sabahat nişanlılıkta savunduğu mesafenin alaturka olduğunu itiraf etse de ahlaklı bir kadın olmanın bunu gerektirdiğini düşünmektedir. Bu yüzden de roman boyunca Suat ile asla yalnız kalmaz; mesafesini her zaman korur.

Romanda kadın-erkek ilişkileri sadece aşk merkezli değildir. Rıfat ve Sabahat arasında hem akrabalık hem de dostluk ilişkisi vardır. Her konuda birbirilerine danışırlar. Rıfat, komşu yalının kızı Fehame’ye âşık olduğunu, Piraye ile evlenmek istemediğini, sevdiği kadını unutmak için yurtdışına gideceğini her zaman ilk olarak Sabahat'e yani teyzesine anlatmıştır.

Sabahat ve Rıfat arasındaki ilişkinin başka örneği romanda görülmez. Kadın-erkek ilişkileri âşı olmak, nişanlanmak ve evlenmek üzerine kurgulanmıştır.

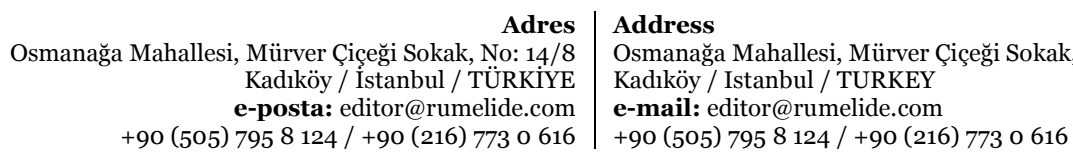




\section{Kadınların kılık - kyyafetleri}

Enîn romanı kılık kıyafet konusunda önemli ayrıntılar vardır. Özellikle genç kadınların kıyafetleri anlatılmıştır: "Piraye'nin kavuniçi muslin entarisi" (s.236), Nebahat’in "açık pembe, parlak ipekli kumaştan beyaz muslin devasa ve dantellerle tezyin olunan elbisesi” (s.271) gibi olay örgüsü ile doğrundan ilişkisi olmasa da yazar, kadınların kıyafetlerini tasvir etmek konusunda çok hassastır. Sabahat’in gündelik bir kıyafetini yazar bütün detayları ile uzun uzun anlatır:

Sabahat beyaz keten bir kostüm giyinmiş idi. Elbiseye bakan, dikişine, kumaşından ziyade para verilmiş olduğunu anlayacağı veçhile gayet güzel biçilip dikilmiş ve usta bir terzi elinden çıkmış olduğunu anlar idi. Elbisede göğüs ve enseyi örten ve bilezikleri teşkil eden ağır bir broderiden başka garnitür yok idi. Kulaklarında her gün bulunan orta büyüklükte, gayet beyaz bir renk taştan başka hulliyat yok idi (s.271).

Sabahat, romanın örnek kadını olduğu için eğitimi, aile içi ilişkileri ve nişanlısına karşı alaturka tavrı kadar doğru kıyafet seçimleri ile de öne çıkmaktadır.

Gündelik yaşamda kılık kıyafetin ortama uyumlu olması bir görgü ve modadan anlama meselesi olarak kabul edilmektedir. Nebahat'in abartılı kıyafetleri Mis Mod tarafından eleştirilir: "Dügüne mi gidiyorsunuz Nebahat Hanım? ... Bu bir hane tuvaleti olmadığı gibi bir vizite kıyafeti de değildir. Elbise modelini kâğıt üstünde gördüğünüz zaman altındaki izahata dikkat ediniz demiştim" (s.271). Nebahat'e yapılan bu uyarı döneme dair önemli bir ipucunu da içermektedir. Demek ki kıyafetler bir moda kataloğundan seçilmekte ve bu katalogda hangi kıyafetin ne zaman ve hangi amaçla giyeceği yazmaktadır.

Kılık kıyafet kimi zaman erkeklerin dikkatini çekmek için kullanılır. Romanda bunun örneği Nebahat'tir. Suat ve Nihat'in dikkatini çekmek için bir akşam oturmasına seçtiği kıyafet şu şekilde anlatılır: "Nebahat geceliklerini giyinmek için arkasından çıkarmakta olduğu ipekli bluzuyla acurlu eteğini yere çarparak itiyordu" (s.286). Ama Nebahat kimsenin dikkatini çekmeyi başaramaz. Çünkü yazara göre kıyafetten önce iyi huylu olmak önemlidir.

Nebahat, Suat'ı elde etmek için kıyafetin tek başına yeterli olmadığını anlamıştır. Bu yüzden Suat'ı kandırmak için buluştuğu gece, hem kıyafetlerine hem sözlerine önem vermiştir. Suat'ın dikkatini çekmek için buluşacakları gece özellikle giyinir ve süslenir: "Nebahat'in sine ve kollar dirseklere kadar açık bir elbise giyinmiş ve duru beyaz renkli olduğu halde o gün mahirane bir surette yanaklarına allık sürmüş" (s.385). Suat'la bahçede buluştuğu ikinci gece, özellikle kılık kıyafetinin açık olmasına çalışmıştır. Bu durum onları uzaktan izleyen Nihat'ın gözünden kaçmaz: "Nebahat'in balo tuvaletlerine mahsus dekolte bir kıyafette bulunduğunu ve yanında bulunan ipek örtüden evvelce örtüyü omuzlarına örtüp geldiği halde orada açılmış olduğunu anlıyordu." (s.390). Nihat'a göre böyle bir kıyafetle buluşmaya gelen bir kızın niyeti iyi ve temiz olamaz. Burada önemli bir nokta da Suat, Nebahat'in kıyafetlerinden etkilenir ama onu en çok etkileyen böylesi kıyafetler içindeki bir kadının aşkından dolayı intihar edeceğini söylemesidir.

Romanda Sabahat, Fehame ve Nebahat'in kıyafetleri özellikle daha detaylı anlatılmıştır. Sıradan bir akşam oturmasında Sabahat'in kıyafetini yazar tarif eder: “O akşam Sabahat'in giyindiği açık pembe renkli libas ile rengîn yanakları rekabete çalışıyor, siyah kadifeden bir kemer o levendane ve muntazam

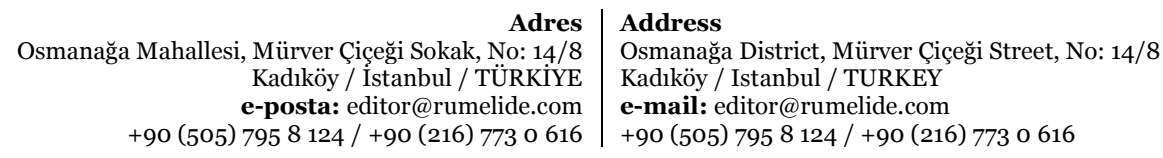


endamdaki ince beli daha ziyade ayan eyliyordu" (s.386). Sabahat doğru kıyafetler seçtiği gibi onları kendine yakıştırmasını da bilmektedir.

Rıfat'ın Fehame'yi gizlice gözetlediği bahçe gezisi sırasında Fehame'nin kıyafetlerini şu şekilde tarif edilir:

Fehame beyaz üzerine kendinden çiçekli bir müslin elbise giyinmiş idi. İçindeki gömleğin işlemeleri görünüyordu. Kolları dirseklere kadar kısa olduğundan demi-dekolte yaka, ense ve sineyi açıkta bırakmış bulunduğundan, beyaz ve şeffaf gibi billuri olan sine, gerdan meydanda idi (s.304).

Roman boyunca Sabahat ve Fehame kıyafetleriyle her zaman öne çıkmayı başarmışlardır. Yazarın burada özellikle vurguladı̆̆ı pahalı ya da abartılı kıyafetlerdense üzerine yakışanı seçmek meselesidir. Aslında yazar, her kadının kendine ait bir tarzı olması gerektiğini savunur.

Romanda Fehame’nin gelinliği şu şekilde tarif edilir:

Havaî canfes üzerine imitasyon brüksel dantel geçirilmiş ve elbisenin bazı yerlerinde mavi renkler gösterilmiş idi. Dantel sahih brüksel olmayıp imitasyon yani taklit ise de öyle olduğu halde elbise yüz liraya mâl olmuş idi. Misafir hanımefendi ile İtimat gelinin kuaförünü yaptılar, gelini giydirdiler. El öptürülmek, para serpilmek gibi rüsum icra olundu. Mükemmel bir saz takımı icrayı ahenk eyledi. Oyuncu kızlar da raks ettiler. Yemekler yenildi, şerbetler içildi (s.329).

Romanda kllık kıyafetleri detayları ile anlatılanlar Piraye, Sabahat, Fehame ve Nebahat'tir. Bunun dışında kalan kadınların kıyafetlerine değinilmez. Evlere yeme içme ve dalkavukluk etmek için gelen kadınları "Falan hanım, filan hanım, birçok hanım. Kimi kaşı rastıklı, kimi alnı çatkılı birçok hanım namında kadınlar!” (s.252) diye tarif edilir. Bu kadınların dış görünüşüne dair başka bir bilgi verilmez. Yazarın kıyafetlerini tarif ettiği kadınların ortak özelliği evlilik çağında olmalarıdır. Piraye, kendisini Rıfat'a beğendirmek ister; Nebahat, Suat ve Nihat'ın dikkatini çekmeye çalışır. Sabahat ve Fehame ise sadece kendileri için giyinirler. Aslında giyinmek ya da güzel görünmek için çaba harcamazlar. Ama yazara göre Sabahat ve Fehame'ye giydikleri her kıyafet yakışır.

\section{Ev içi eğlenceler}

Eğlence, boş zaman etkinliğidir. Boş zaman kavramı modern hayatla birlikte gündelik yaşam alanına girmiştir. "Boş zaman, gereksinimler arasına giriyor ve önceden var olan gereksinimleri değişime uğratıyor. 'Modern hayat'ın yorgunlukları, eğlenmeyi, hoşça vakit geçirmeyi, gevşemeyi gerekli kılıyor" (Lefebvre, 2016, s.65). Boş zaman ve bunu eğlence ile değerlendirmek bolluk ve zenginlik göstergesidir. Romanda eğlence hayatının merkezinde kadınlar vardır. Erkekler dinleyen ve izleyen konumundadır. Kadın eğlendiren, erkek ise eğlenendir. Ama Enîn'de kadınların eğlenceleri ev içi yaşamın izin verdiği ölçüdedir. Bu eğlencelerin başında müzik ziyafetleri, bahçe gezintileri, komşu ziyaretleri ve düğün gelmektedir.

\subsection{Müzik}

Enîn romanında müzik önemli bir boş zaman etkinliğidir. Ama müzik sadece zaman geçirme aracı olarak görülmez. Müzik ve sanat felsefesinin iç içe olması hakkında konuşmalar yapılır. Hissetmeden sanat icra etmenin anlamsız olduğu üzerinde durulur (Günaydın, 2018, s.159). Piraye de Fehame de ud ve kanun çalmaktadırlar. Ama Fehame hissederek çalar ve Rifat da buna âşık olur. Piraye'nin ise sanattaki hissizliğini yazar şu cümlelerle değerlendirir: "Evet Piraye karcığar peşrevini bilânoksan çalıyordu. İyice ezberlemiş idi. Lakin o ezbercilik ile bu ûdîler arasında ne büyük fark var idi!” (s.260).

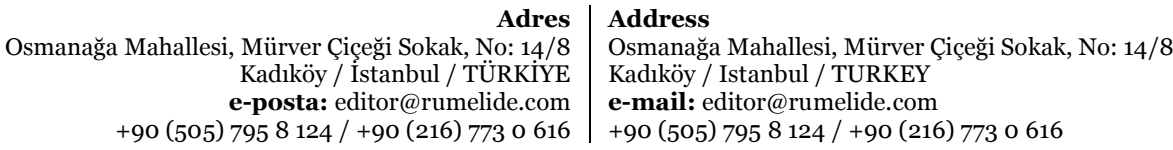


Yazar burada sanatın sadece eğlenmek ve zaman geçirmekten ibaret olmadığını, bir felsefesinin, bir derinliğinin olduğunu vurgulamak istemiştir. Bu derinlik ve sanat felsefesini romanda Sabahat, Fehame ya da Rıfat gibi iyi eğitim görmüş kişiler anlamaktadır. Piraye şeklen müzik aletlerini çalmayı bilse de karşı tarafa duyguyu geçiremez. Çünkü kendisi de müziğin ruhunu hissedemez.

Romanda neredeyse bütün kadınların çalmayı bildiği bir müzik aleti vardır. Fehame evin bahçesinde ud çalıp şarkı söyler:

Anladılar ki önce dinledikleri mahirane taksim Bedia tarafindan idi. Şimdi de Fehame taksim ediyordu. Gittikçe parlayan ruh-nevaz nağmeler kaybolmağa, derin, elim esvat-ı şikâyat işitilmeğe başladı. Ud inliyor, giryeler, eninler isale ediyordu (s.261).

Romanda Fehame ud çalarken "bir sanatkâr eliyle çalınan ud" diye anlatılan bu sahnede, yazar sanatın ve müziğin felsefesini vurgulamak istemiştir.

Alafranga evlerin en önemli aksesuarlarından biri olan piyano, Enîn'de de vardır. Ekrem Bey, ailecek salonda oldukları bir vakit, yeğeni Sabahat'in piyano çalmasını ister. "Sabahat Şopen’in parçalarından bir kaçını kemal-i maharetle çaldı” (s.273). Sabahat'in yanı sıra Mis Mod ve İtimat da piyano çalabilmektedirler (s.273). Bu piyano ziyafetinde dikkat çekici olan ailenin erkeklerinin de bulunduğu bir ortamda gerçekleştirilmesidir. Ekrem Bey, evlilik çağındaki oğulları Nihat ve Suat, komşu yalıdan Rıfat ve evin kadınları hepsi Sabahat'in ve İtimat'ın kendilerine çaldıkları parçaları keyifle dinlemektedirler (s.274). Bu müzik ziyafetinde hem batının hem doğunun parçaları çalınmıştır. Hem neşeli hem hüzünlü havalar tercih edilmiştir.

Bir akşam vakti evin bütün gençleri toplanıp müzik aletleri konusunda hünerlerini sergilerler:

Rıfat'ın tensibi üzerine Piraye'ye bir kanun verdiler, Sabahat udu aldı, Rıfat da kemanı aldı. Piraye takımla beraber pek âlâ gidiyordu. En usta bir kanuncu da o kadar çalabilirdi. Bu parlak çalışı görenler Piraye'den taksim istediler. Piraye hiç usulden çıkmaksızın bir taksim yaptı. Biraz sonra Rıfat kemanı aldı. İtimat'ı da yanına çağırdı. Rıfat taksime başladı. İtimat'a hicazdan bir yol açtı. İtimat hazin ve gümrah sadasıyla gazele başladı (s.296).

Bu sahnede İtimat'ın bu kadar başarılı olmasından Sabahat büyük bir mutluluk duyar. Çünkü İtimat kendisine verilen eğitimin hakkını vermiştir. Aynı şekilde Piraye de elinden geleni yapmıştır. Burada dikkati çeken bir diğer husus da ud ve kemanın doğu ve batının imgeleri ve iç içe geçtiğinin işareti biçiminde gösterilmesidir.

Romanda müzik, birleştirici bir etkinlik olarak karşımıza çıkmaktadır. Kimi zaman aile büyükleri ile birlikte kimi zaman gençler baş başa olduklarında müzik etrafında birleşip eğlenirler. Kimi zaman da Fehame'de olduğu gibi üzüntüleri dile getirmenin bir yolu olmuştur.

\subsection{Düğün}

Romanda sadece Fehame'nin düğünü gerçekleşmiştir. Suat ve Nebahat ailelerden gizli bir nikâh yapmışlardır. Bu nikâha dair başka bilgi verilmez. Bir eğlence ya da tören düzenlemezler. Suat'ın Sabahat ile nişanlı olduğu söylenir. Buradaki nişan söz verme anlamındadır. Aile büyükleri, Suat ve Sabahat'i birbirine uygun bulur; gençler de evliliğe onay verince nişanlanmış kabul edilir. Sabahat ve Suat ayrıldıkları için düğünleri olmaz. Ama Sabahat'in dügün hazırlıklarından, gelinlik ve çeyizden bahsedilir. 
Fehame ailesi tarafından seçilen ve hiç görmediği evlenmek de istemediği biriyle evlenmek zorunda kalır. Bunun için dirense de başarılı olamaz. Önce nikâh, üç hafta sonra da düğünü olur. Son güne kadar kendi düğünü olduğu Fehame'den saklanır. Annesi Lütfiye Hanım kızına gereken düğün masrafını yapamaz. Fehame'nin dügünü için babası gereken parayı Lütfiye Hanım’a verir. Ama Lütfiye Hanım bu parayla "hane halkına, dairenin temelli dalkavuklarına, gelip gidici kâse-lîslere hep güzel elbiseler, çoğuna ipekliler” (s.345) alır. Bu yüzden de gelinin çamaşır ve levazımı para kalmadı̆̆ı için yapılamaz:

Düğünde göze görünecek şeyler pek mükemmel olduğu halde yüz liralık sırmalı elbiseyi giyecek olan gelinin sandığına yarım düzine olsun mendil ve çorap konulamadığı gibi değişecek iki üç gecelik entari ve gömlek de yapılamadı. Sırmalar içinde bulunan yatak takımına değişecek ne çarşaf ve ne de yorgan çarşafı yapilamadı (s.345).

Düğün boyunca önemli olan tek şey gösteriştir. Bu yüzden Lütfiye Hanım sadece herkesin göreceği şeylere para harcar gelinlik, verilen yemekler ve eğlence ortamı gibi: "Birkaç takım sazlar, oyuncular, mükemmel sofralar, taamlar ile düğün pek tantanalı oldu. Paça günü de perşembeden farksız oldu" (s.345). Lütfiye Hanım, düğün için verilen parayı gösterişe harcayınca komşuları Sabahat Hanımlardan yardım ister. Hem onları düğüne davet eder hem de onlardan "taç varsa geline takılmak üzere o gün için" (s.327), ödünç bir gelin tacı ister. Bunun dışında "ağır bir bilezik" (s.327) ve "gelinin başının bağlanmasına da nezaret” (s.327) etmelerini de ister. Düğün zamanı önce nikâh icra edilir. Ardından da selamlık tarafında erkeklere yemek verilir. (s.328). Sabahat, arkadaşı Fehame'ye düğünde takması için "bir taç, bir gerdanlık, bir küpe, bir de bilezik" götürmüştür. Düğün bitince Fehame gündelik kıyafetlerini giyer, üzerinde Sabahat’ten aldığı takıları çıkarıp iade eder.

Fehame’nin düğününden bahsederken yazarın vurguladığı iki temel husus vardır. Anne Lütfiye Hanım'ın gösteriş merakı ve Fehame’nin fakirliği. Düğün parasıyla başkalarını etkilemek ve zenginliklerini vurgulamak için en uzak komşuya, tanıdığa kadar herkese hediyeler, kıyafetler alınırken; Fehame'ye gereken takılar, çeyizler, eşyalar alınmaz. Bu bölümün en çarpıcı sahnesi ise düğün bitip de misafirler gittiğinde Fehame'nin ödünç takıları sahibine verip gündelik kıyafetlerini giymesidir.

Romanda Sabahat ve Suat'in düğünü son haftaya gelindiğinde iptal olur. Ama düğün hazırlıkları anlatılır:

Gelinlik ve paçalık elbise de yarınki posta ile gelecekmiş. İşlemeli şeyler de bitmek üzere. Her şey hazırlanacağından düğün üçüncü hafta bilâşüphe olacaktır. Annelerin Sabahat’i telli pullu görmek arzusu olmaya idi bir de sırmalı gelinlik entari işletilmek meselesi bulunmaya idi düğün ikinci haftada icra olunabilecek idi. Sabahat gündüz beyaz dantel angllter elbisesini giyecek, koltuk resminde kendisini öyle göreceksiniz. Akşamüzeri sırmalı elbisesiyle bir Türk gelini olacak (s.359$360)$.

Sabahat romanın başından beri kllık-kıyafet konusunda zevk sahibi olduğunu göstermiştir. Gelinliği de ona yakışır bir biçimdedir. Sabahat hem zevk sahibi hem de para sahibidir. Annesinden kendisine büyük bir miras kalmıştır. Düğün hazırlıklarını bu parayla yapmıştır. Yazar bu maddi detayı özellikle vurgulamıştır.

Romanda gerçekleşen düğünde dönemin âdetlerine dair ipuçları bulmak mümkündür. Ama sevmediği bir adamla evlendirilen bir kızın düğünü anlatıldı̆̆ı için eğlence yönü bilerek zayıf tutulmuştur. Yazar düğünü değil gelinin mutsuzluğunu öne çıkarmıştır.

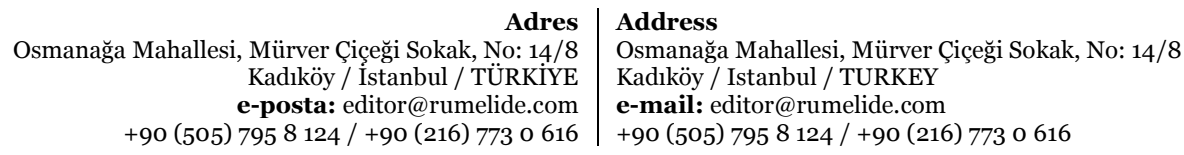




\subsection{Ev gezmeleri}

Romanda ev gezmeleri ikiye ayrllır. Birincisi yan yana üç yalı sakinlerinin özellikle de gençlerin birbirine gidip gelmeleridir. Fehame ve ailesi diğer yalıya taşındığında evin kadınları yeni aile ile tanışmak ve hayırlı olsun demek için gezmeye giderler.

Gençlerin birbirlerine gelip gitmeleri de hayat anlayışları ve ortak yönlere göre şekillenmiştir. Fehame, eğitim olarak kendisine denk konumdaki Sabahat ile iyi arkadaş olur:

Rıfat'ın hastalığı zamanına kadar Sabahat, Fehame ile pek iyi görünüyordu. Rıfat yataktan kalktıktan sonra bazan Sabahat onun yanına gitmekte, bazan da Rıfat, Sabahat'in yanına gelmekte olduğundan Sabahat, Fehame’ye gidememiş idi. Fehame birkaç defalar geldiği halde iade-i vizite olunmadığından artık cesaret edip gelemiyordu (s.320).

Ev gezmelerinde günümüzde olduğu gibi o zaman da iade-i ziyaret yapılmasının önemli olduğu anlaşılmaktadır. Sabahat, Fehame'yi gerektiği gibi ağırlayamadığı ve ziyaretlerine karşılık veremediği için Fehame bir daha ziyarete gelemez.

Romanda ev gezmesinin diğer örneği olarak da fakir mahallelerde oturan ve yalıdaki zenginlerin ihsanları ile yaşayan kadınları görürüz. Bu kadınlar, ziyaretlerine karşın iade-i ziyaret beklemezler. Bu kadınları yazar: "çanak yalayıcı tabir olunan kısım ise tekâpu ve tabasbusun son derecelerine varırlardı" (s.338) diye anlatır. Bu kadınlar yalılarda hazırlanan sofralara oturabilmek, bayramlarda ve düğünlerde hediye alabilmek için dalkavukluk ederler. Özellikle Lütfiye Hanım'ın etrafında böyle kadınlar daha çoktur. Romanda bu kadınların en bilineni olan Vesile Hanım anlatılır: "Bütün yalılara gider, yalılarda ve köşklerde bulunan kibarların ianeleriyle geçinirdi. Yiyeceği olmadı̆̆g vakit öğle ve akşam yemeklerini yalıların veya köşklerin birinde yerler, elbiseleri kalmadığı vakit onlardan isterlerdi" (s.321-322). Romancıya göre "bu gibi kadınların en büyük meşguliyetleri konaktan konağa lakırdı taşımak, bir yerde görüp işittiklerini öbür tarafa nakl ve hikâye eylemek”tir (s.322). Bu yüzden evlerine gelen Vesile Hanım'dan Sabahat, Fehamelerin yalısına ve ailesine dair bilgiler öğrenmeye çalışır.

Nikâhtan sonra Fehame üzüntülerini unutmak için Sabahat'in yalısına gelir. Birlikte bahçeye inerler. Bahçede kahve içip sohbet ederler. Sohbet konuları eş seçimi ve mutlu bir evlilik hayatı üzerinedir. (s.336). Her konuda çok iyi anlaşırlar ama birbirlerine yardımları dokunmaz. Özellikle de Sabahat, Rıfat'ın Fehame'ye olan aşkını bildiği halde asla söylemez. Sadece Fehame'nin mutsuz evliliğine üzülmekle yetinir.

Romanda ev içi eğlencelere düşkün olanların başında Fehame'nin annesi Lütfiye Hanım gelir. "Ehibbası pek çok idi. Hanesinde pek çok ziyafetler olur ve eğlenceler ihdas ve icadıyla hoş günler geçirmeğe çalışırdı. Kendisi pek afif, musahebeti lâtif, ehibbasına muamelesi zarif ve ikramı mebzul olduğundan ehibbası kendisiyle ülfetten hoşlanırdı" (s.338). Lütfiye Hanım’ın eğlencelerini kendisine ziyarete gelen ve ondan ihsan uman kadınlar ve o kadınların övgüleri oluşturmaktadır.

\subsection{Bahçe gezintileri}

Romanda her yalının kendine ait ama komşu yalılardan da kısmen görülen bakımlı bahçeleri vardır. Dolayısıyla bahçe, mekânın bir parçasıdır. Bahçe gündelik yaşamda nefes alma, sevdiği kadını/erkeği görme, nişanlıların aile ya da dadı gözetiminde buluşma yeri olarak karşımıza çıkmaktadır. Kimi zaman gizli buluşmalar için de bahçe kullanılmıştır. Genç kızların diğer yalıdaki kızlar ile buluştuğu,

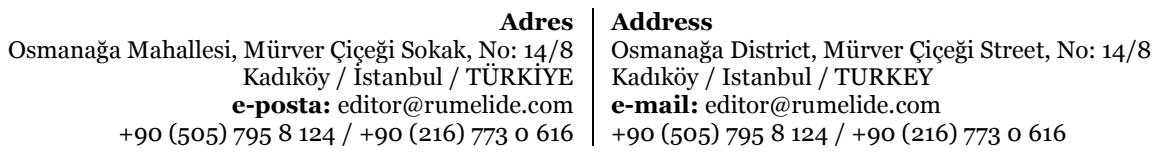


özel meselelerini konuştuğu ya da keman çalıp şarkı söyledikleri bir mekân olarak da bahçe karşımıza çıkmaktadır.

Sabahat'in Suat ile evlenmesi uygun görüldüğünde genç çift ilk kez bahçede evlilik konusunda konuşurlar. "Çamların altındaki kanepelerin birine Sabahat oturdu. Bahçelere mahsus bir hasırlı koltuğa da Suat oturdu. Mis Mod çağlayan seddindeki kanepeye oturmuş, konuşulan sözleri iyice işitemeyecek ise de onları görecek bir mevkide bulunuyordu" (s.277). Elbette bu konuşma Mis Mod ve aile büyüklerinin uzaktan gözetimi altında gerçekleşir. Nebahat ve Suat gizlice bahçede buluşur. Rıfat, Fehame'yi bahçe gezmeleri sırasında görür.

Romanda yalıların bahçeleri kimi zaman bir kaçış, kimi zaman bir buluşma, kimi zaman misafir ağırlama mekânı olarak karşımıza çıkmaktadır.

\section{Ev içi eğitim}

Fatma Aliye, Enîn romanında evlilik ve iyi bir eş seçimi kadar ısrarla üzerinde durduğu diğer bir konu da kadınların eğitimidir. Romandaki bütün genç kadınlar eğitimlidir. Romanda bahsi geçen üç yall, genç kadınlar için okul halini almıştır. Ders vermek için eve gidip gelen özel hocalar, Fransızca ve İngilizce dillerini ilerletmek için aileler tarafından yabancı ülkeden getirilen eğitmenler romanlarda ev içi yaşamda kendilerine yer bulurlar. Sabahat, Nebahat, Piraye ve İtimat eve gelen özel hocalardan ders alarak büyümüşlerdir:

Sabahat'in eğitimi için en muteber muallimler tayin eylediği gibi Fransızca lisanı için getireceği muallimeyi de kendisi Paris'e kadar gidip ehibbası vasitasıyla intihap eyledi. ... Sabahat, İtimat'la beraber derslerini beller, onunla oynar, zaman geçirirdi. Sabahat, Fransız lisanına tamamıle kesb-i vukuf ve meleke hasıl edip de muallimesi memleketine gittiği zaman İtimat'la Fransızcayı pek mükemmel konuştuklarından Sabahat'in Fransizcadaki melekesini kaybeylemek korkusu yok idi. Londra'dan getirtilen Mis Mod'dan dahi İngilizce'yi birlikte öğrendiler (s.247).

Romanda kadınların eğitimine dair en detaylı bilgiler Sabahat ve Fehame hakkındadır. Dayısı Ekrem Efendi, Sabahat'in iyi bir eğitim alması için dönemin en önemli hocalarından Abdullah Efendi'den yardım ister:

Abdullah Efendi’nin Cuma ve Pazar günlerinden başka tatili olmadığından o günler derse geldikten başka bazı geceler de derse gelir. Bu veçhile Sabahat, kavait, mantık, belâgat, ilm-i âdab, münazara, coğrafya, tarih, kozmografya, hikmet, kimya derslerine Abdullah Efendi'den başladığı gibi Sabahat büyüdükçe dersler de büyümekte idi (s.320).

Romanda Fehame'nin çok iyi derece Fransızca konuşup yazması, felsefeden edebiyata dair pek çok alana hâkim olması iyi bir eğitim aldığını göstermektedir:

Görüyordu ki Fehame pek güzel Fransızca söylüyor ve Fransızcadan her okuduğu kitabı pek güzel olarak anlıyor. Türkçede pek parlak ve düzgün bir kitabete maliktir. Hatta bazı kere Sabahat'e Fransızca olarak yazdığı tezkireler de pek kusursuzdu. Fehame, Türk ve Fransız edebiyatına vakıf, felsefeden bahseder, mükemmel tarih bilir (s.321).

Fehame'nin eğitim hayatıyla ailesi başkalarından övgü duymak için ilgilenmiştir: "Âdet yerini bulsun, Safi Efendi'nin kızı iyi tahsil ettiriliyor denilsin diye en mükemmel muallimlerden ders aldırılıyor, lakin çocuğun ne okuduğu ve çalışıp çalışmadığı ile iştigal olunmuyordu.” (s.339) Fehame örtüye sokulup da selamlıktan ayrılınca Fransızcasını geliştirmesi için Paris’ten genç bir kız getirilmiştir. Bu kız Fehame'ye "Fransızcadan pek ciddi eserler" okutur (s.341). Ailenin kzzlarına en iyi hocalardan eğitim aldırması ve bu uğurda çok para harcamasının nedeni başkalarının bu konuda neler diyeceğidir.

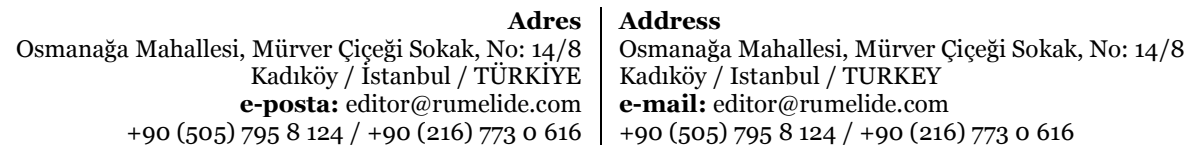


Enîn'de eğitim konusunda sınıfsal ayrım yapıldığı görülmektedir. Romanda cariyeler dâhil (İtimat ve Piraye) bütün genç kadınlar ev içi iyi bir eğitim görmüştür. Sabahat ve Fehame eğitim hayatlarında başarılı olurlar. Nebahat yaramaz olduğu için ablası kadar başarılı değildir. Ama İtimat ve Piraye eğitim konusunda Sabahat ve Fehame'nin seviyesine gelemezler. Onlar cariyesi oldukları evin isteklerini karşlayacak kadarını öğrenmişlerdir. Efendileri ile dil pratiği yapmak için Fransızca ve İngilizce (s.247); onları eğlendirmek için keman, ud ve kanun çalmayı öğrenirler (s.296). Piraye, cariye olarak alındığı evde kız evlat muamelesi görmüştür. Mesile Hanım, Piraye'nin eğitimi ile yakından ilgilenmiştir. Ama yazara göre Piraye, Sabahat ve Fehame kadar başarılı olamamıştır:

Piraye, latif kızcağız! Tahsiline epeyce himmet olunmuş, kendisi de çalışmakta kusur etmemiş ise de okuduklarını bellemekte kalıp faaliyet-i fikriyesi ondan ilerisini merak ile tefekkürat-ı amikaya ve zekâ-yı tabiîsi istikşaf ve idrak-ı hakayık-ı âleme ilerleyecek mertebede değil idi. Asla budala ve ahmak değil idi. Lakin orta bir zekâsıyla Sabahat ve Fehame gibi kimselerle kıyas olunamazdı (s.422).

Romanda başta Sabahat ve Fehame olmak üzere kadınların aldıkları eğitimleri değerlendirecekleri, onlarla hayatta kendilerine yeni bir iş ya da hayat kuracak ortamları yoktur. Bu bağlamda kadınların ev içi eğitimi o dönemin zengin aileleri için bir gereklilik gibi yorumlanabilir. Özellikle ailesi tarafından yeterince sevgi ve şefkat görmeyen Fehame'nin eğitimi için yapllanlar bu düşünceyi somutlaştırmaktadır.

Romanın sonunda nişanlısından ayrlan Sabahat ve kocasıyla mutsuz olan Fehame, mutluluğu ve huzuru "tahsile devam" etmekte bulurlar. Abdullah Efendi'den "hikmet-i tabiîye, kimya, heyet, tarih-i umumî evvelce okumuşlardı. Ulûmun derinlerine giriştiler, filosofiye daldılar. O zamana kadar okuduklarının ilerisine doğru gitmekte idiler" (s.421). Sabahat ve Fehame'nin yaşadıkları sorunlara rağmen eğitime sığınmaları dikkate değerdir. İtimat ve Piraye'nin yetişkin olduktan sonra eğitimlerine devam ettiklerine dair bir bilgi yoktur. Evin hanımlarının istediği kadar eğitim görmüşler ama bunu ilerletecek ya da değerlendirecek bir girişimleri olmamıştır.

Romanda kadınların eğitim başarıları ile ahlakları ve konumları ilişkilidir. İtimat ve Piraye ahlaken iyi olsalar da cariye oldukları için eğitimde ileri bir dereceye gelemezler. Yazar bunu açıkça ifade etmez. Ama İtimat ve Piraye'yi her defasında Sabahat ve Fehame ile karşlaştırarak bunu hissettirir. Nebahat ise ahlaken kötü huylu olduğu için aldığı eğitimin hakkını veremez. Sabahat ve Fehame ise eğitimde birbirlerine denktirler. Bu yüzden roman boyunca iyi arkadaş olurlar.

\section{Sonuç}

Modernleşme dönemi Türk romanında mekân, toplumsal değişimleri yansitan önemli bir göstergedir. Bu mekânlar arasında ev, kadınların yaşam alanı ve bu alanda meydana gelenleri göstermesi açısından öne çıkmaktadır. Fatma Aliye, Enîn romanında 19.yüzyıl Türk kadının ev içi yaşamını kurmacanın imkânları ile sergilemiştir. Romandaki kadınların ev içi yaşamının merkezinde evlilik konusu vardır. Romanda kadınların gündelik yaşamı belli rutinlerden oluşmaktadır. Eğitimlerine devam etmek, dil pratiği yapmak, kitaplar hakkında konuşmak, müzik ile vakit geçirmek gündelik rutinleridir.

Enîn romanı dönemin zengin ailelerinin gündelik yaşamını anlatmaktadır. Bu yüzden boş zaman etkinlikleri gündelik yaşamda önemli bir yer tutar. En önemli boş zaman etkinliğinin başında müzik gelmektedir. Müzik dışında misafir ağırlama, misafirliğe gitme, kitap okuma, kataloglardan kıyafetler seçme kadınların gündelik yaşamını oluşturmaktadır. Ailelerin ekonomik durumlarının iyi olması, geçinme ve ev işi derdinin olmaması da gündelik yaşamı şekillendirmiştir. Romanda ev işleri isimsiz

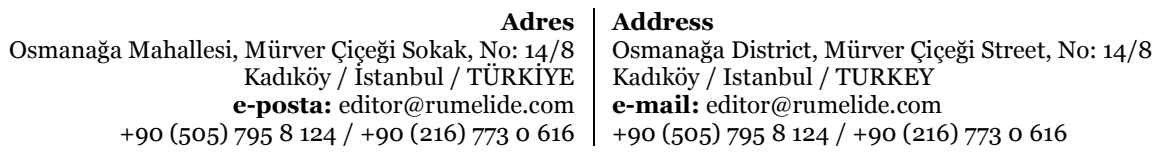


cariyeler tarafından yapılmıştır. Ama bu kadınların isimleri, hayatları ya da onlara dair başka bilgiler romanda yer almaz. Romanda akıllı kadınlar kendilerine verilen eğitim olanaklarını sonuna kadar kullanmışlardır. Sabahat ve Fehame bunun örneğidir. Arkadaşlık ilişkileri bile kitaplar ve dersler üzerine kuruludur. Her iki genç kadın da gündelik yaşamlarında olgun tavırları ile öne çıkmaktadır. Kılık kıyafet seçimleri, aile büyüklerine karşı saygılı tutumları, ders aldıkları her hoca tarafından sevilip övülmeleri bu olgunluğun göstergesidir.

Romanda mekânın sınırlarının aşıldığı iki alan vardır: Dil ve mûsikî. Romanın bütün genç kadınlarının Fransızca, İngilizce gibi yabancı dilleri iyi derecede bilmeleri; ud, keman, piyano gibi doğuya ve batıya ait müzik aletlerini çalabilmeleri dünyayla kurdukları bir bağ olarak düşünülebilir.

Sonuç olarak romanın görünen dünyasında kadınların aşkları, evlilikleri, mutluluk ve mutsuzlukları vardır. Yazar, iyi eğitim, sade yaşamla düzgün evlilik ve mutluluk arasında bağ kurmuştur. İdeal bir son ve mutsuz son göstererek okurun ders çıkarmasını istemiştir. Romanın fonundaysa 19. yüzyl sonu-20. yüzyıl başında kadınların ev içi yaşamına dair birçok ayrıntıya yer verilmiştir. Bu ayrıntıların, bir kadın yazar tarafından betimlenmesi sosyal tarihin görünürleşmesi, kadınların yaşamının pek bilinmeyen iç ayrıntılarının anlaşılması açısından önemli bir romandır.

\section{Kaynakça}

Alver, K. (2019). Türk romanında kentsel mekânlar ve toplumsal değişme ilişkisine kısa bir bakış. Toplumsal Değişim, 1, 121-139.

Argunşah, H. (2016). Kadın ve edebiyat babasının kızı olmak... İstanbul: Kesit.

Faroqhi, S. (2005). Osmanlı kültürü ve gündelik yaşam (Çev. Elif Kılıç). İstanbul: Tarih Vakfı.

Fatma Aliye (2015). Enîn. (Hzrl. Tülay Gençtürk Demircioğlu). İstanbul: Boğaziçi Üniversitesi.

Günaydın, A. U. (2018). Kadınlk daima bir muamma Osmanl kadın yazarlarn romanlarnda modernleşme. İstanbul: Metis.

İnci Elçi, H. (2003). Roman ve mekân: Türk romanında ev. İstanbul: Arma.

Lefebvre, H. (2016). Modern dünyada gündelik hayat (Çev. Işın Gürbüz). İstanbul: Metis.

Karaca, Ş. (2013). Modernleşme dönemi Türk romanında evden kaçan ve eve sığınan kadınlar. Turkish Studies. 8(1)., 1817 - 1827.

Tekin, M. (2011). Roman sanatı romanın unsurları I. İstanbul: Ötüken.

Taş, T. (Ed.) (2011). Edebi gündelik. Ankara: Deki.

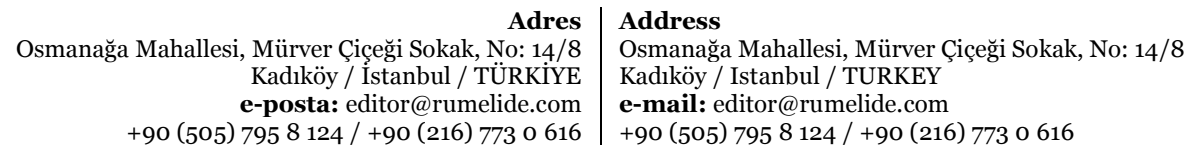

